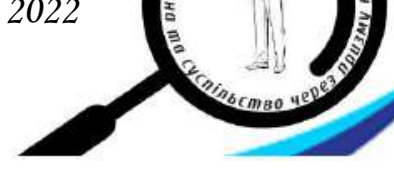

УДК 330.322

https://doi.org/10.52058/2786-5274-2022-1(3)-165-182

Мулик Тетяна Олексіївна кандидат економічних наук, доцент, доцент кафедри аналізу та аудиту, Вінницький національний аграрний університет, вул. Сонячна, 3, м. Вінниця, 21008, тел.: (067) 961-32-26, https://orcid.org/00000003-1109-2265

\title{
КАПІТАЛЬНЕ ІНВЕСТУВАННЯ В УКРАЇНІ: СТАН, ПРОБЛЕМИ ТА ПЕРСПЕКТИВИ РОЗВИТКУ
}

Анотація. Економічна діяльність окремих господарюючих суб'єктів, регіонів і країни в цілому, значною мірою характеризується обсягом і формами здійснюваних інвестицій. Капітальні інвестиції $\epsilon$ каталізатором розширення можливостей підприємства, що сприяє його розвитку. В статті проведено оцінку та визначено проблеми та перспективи розвитку капітальних інвестицій підприємств України.

Проаналізовано валове нагромадження основного капіталу в Україні в 2001-2020 pр., \% до ВВП, зазначено, що в 2020 році рівень валового нагромадження основного капіталу до ВВП склав лише 12,8\%, що стало історичним мінімумом з початку 2000-х років. Проаналізовано динаміку обсягу капітальних інвестицій в Україні за видами економічної діяльності та за видами активів протягом 2016 - 2020 років. Оцінено також капітальні інвестиції в Україні за джерелами фінансування за 2018-2020 роки. Визначено, що розміри капітального інвестування поки що залишаються на низькому рівні. Така ситуація спричинена несприятливим інвестиційним кліматом, який асоціюється 3 рядом проблем, зокрема: нестабільність і недосконалість нормативно-правової бази, політична нестабільність, недостатній рівень розвитку валютного регулювання, нерозвинутість фондового ринку, значний податковий тиск, низький рівень забезпечення привабливості об'єктів інвестування, малоефективна інвестиційна діяльність банків, низький рівень трансформації заощаджень населення в інвестування, недостатня кількість вільних економічних та офшорних зон, корупційні процеси тощо. Зазначено, що на інвестиційний попит в крані, інвестиційну активність суб'єктів господарювання, обсяги інвестицій, впливають також наслідки пандемії COVID-19.

Зазначено, що для того аби збільшити інвестиції в підприємницьку діяльність, необхідно: вдосконалити нормативно-правову базу, яка б чітко визначала права інвесторів та давала їм можливість вільно вкладати вільні кошти в підприємства України; створити освітні центри, які б навчали та інформували громадян України щодо інвестиційної діяльності, а також 
надавали приклади щодо залучення іноземних інвесторів; запозичити міжнародний досвіт щодо інвестиційної діяльності підприємств. Заходи щодо активізації інвестиційної діяльності суб’єктів господарювання мають здійснюватись на всіх рівнях та етапах господарювання. Необхідно забезпечити сприятливий інвестиційний клімат не лише для іноземних інвесторів, але й для українських. Пожвавлення інвестиційної активності здійсненне шляхом комплексних, рішучих та послідовних дій, сприятимуть створенню конкурентного осередку та стимулів ефективного розвитку суб’єктів господарювання та економіки країни в цілому.

Ключові слова: капітальні інвестиції, інвестиційна діяльність, інвестиційна привабливість, інвестиційний попит.

Mulyk Tetiana Oleksiivna PhD in Economics, Associate Professor, Associate Professor of Analysis and Audit Department, Vinnytsia National Agrarian University, Soniachna St., 3, Vinnytsia, 21008, tel.: (067) 96132 26, https://orcid.org/0000-0003-1109-2265

\section{CAPITAL INVESTMENT IN UKRAINE: STATE, PROBLEMS AND DEVELOPMENT PROSPECTS}

Abstract. The economic activity of individual economic entities, regions and the country as a whole is largely characterized by the volume and forms of investment. Capital investment is a catalyst for enterprise empowerment, which contributes to its development. The article evaluates and identifies problems and prospects for the development of capital investment of Ukrainian enterprises.

Gross fixed capital formation in Ukraine in 2001-2020, \% of GDP, is analyzed, it is noted that in 2020 the level of gross fixed capital formation in GDP was only $12.8 \%$, which was the historical minimum since the early 2000 year. The dynamics of the volume of capital investments in Ukraine by types of economic activity and by types of assets during 2016 - 2020 is analyzed. Capital investments in Ukraine are also estimated according to the sources of financing for 2018-2020. It is determined that the size of capital investment still remains low. This situation is caused by unfavorable investment climate, which is associated with a number of problems, including: instability and imperfection of the regulatory framework, political instability, insufficient development of currency regulation, underdeveloped stock market, significant tax pressure, low attractiveness of investment objects, inefficient investment activity of banks, low level of transformation of household savings into investment, insufficient number of free economic and offshore zones, corruption processes, etc. It is noted that the investment demand in the country, the investment activity of economic entities, the volume of investments is also affected by the consequences of the COVID-19 pandemic.

It is noted that in order to increase investment in entrepreneurial activity, it is 
necessary to: improve the regulatory framework that would clearly define the rights of investors and give them the opportunity to freely invest free funds in Ukrainian enterprises; create educational centers that would train and inform the citizens of Ukraine on investment activities, as well as provide examples of attracting foreign investors; to borrow international experience in investment activities of enterprises. Measures to intensify the investment activities of economic entities should be carried out at all levels and stages of management. It is necessary to ensure a favorable investment climate not only for foreign investors but also for Ukrainian ones. The revival of investment activity is possible through comprehensive, decisive and consistent actions, will contribute to the creation of a competitive center and incentives for effective development of economic entities and the economy as a whole.

Keywords: capital investments, investment activity, investment attractiveness, investment demand.

Постановка проблеми. На сучасному етапі господарювання важливою проблемою економіки України $є$ піднесення вітчизняного виробництва як головного напряму економічного розвитку, що дає можливість створювати робочі місця та залучати інвестиційні ресурси.

Піднесення вітчизняного виробництва, ефективність діяльності підприємств залежать від ряду чинників, де вагоме місце відводиться інвестиційній активності господарюючих суб’єктів щодо реалізації капітального інвестування. Наслідком інвестування в економіку вітчизняних підприємств $\epsilon$ оновлення та модернізація основних засобів, ріст продуктивності наявних потужностей, застосовування інноваційних технологій, зменшення енергомісткості виробництва а також ступеня шкідливого впливу на природнє середовище, поліпшення процесів екологізації тощо. Все це сприяє розвитку підприємств у ринковому середовищі, а отже i розвитку економіки держави. Тому актуальним нині $є$ питання дослідження сучасних тенденцій щодо капітального інвестування, виявлення проблем та перспектив їх розвитку. Необхідність посиленого нарощення розмірів капітальних інвестицій в країні задля оновлення вкрай зношених виробничих потужностей, вирішення соціально-економічних та екологічних питань та запровадження інновацій у виробництво 3 ціллю поліпшення ефективності та конкурентоспроможності вітчизняної економіки додає актуальності даному дослідженню.

Аналіз останніх досліджень і публікацій. Дослідженню інвестиційної діяльності підприємств присвячено праці багатьох вчених, серед яких В. Геєць, Ю. Бажал, О. Білоусова, А. Загородній, Ю. Стадницький, В. Кентон, П. Кузьмович, Т. Остапчук, А. Пересада, К. Паливода, Т. Радевич, Й. Ридаровська, Ю. Подмешальська, С. Мельник, О. Ярмолюк, О. Дмитренко, Т. Майорова, В. Крук, Я. Шевчук, Т. Мулик та інші. Авторами представлено 
сутність та склад капітальних інвестицій, наведено ознаки їх класифікації та методи стимулювання; обгрунтовано потребу в уточненні сутності категорії “капітальні інвестиції” з метою вдосконалення організації їх обліку; розкрито нові підходи до визначення змісту і форм капітальних інвестицій та основні проблеми їх реалізації. Розам з тим $є$ потреба в дослідженні проблем та перспектив розвитку капітальних інвестицій з врахуванням нинішньої ситуації, що склалась в Україні.

Мета статті - оцінка процесів капітального інвестування в Україні, визначення проблем та перспективи розвитку капітальних інвестицій.

Виклад основного матеріалу. Економічна діяльність окремих господарюючих суб'єктів, регіонів і країни в цілому значною мірою характеризується обсягом i формами здійснюваних інвестицій. Питання залучення інвестицій у нинішній час набуває особливої актуальності. Адже саме наявність інвестицій, їх адекватність потребам розвитку обумовлює соціально-економічну стабільність та рівень розвитку регіонів, їх економічну безпеку.

Інвестиції слугують підгрунтям розвитку не лише суб'єктів господарювання окремих галузей, а й економіки країни в цілому [1, с. 47].

Капітальні інвестиції і $є$ тим самим каталізатором розширення можливостей підприємства, що сприяє розвитку підприємства та їх економіки в цілому. Використання застарілих основних засобів та технологій виробництва призводить до виробництва неякісної, а тим самим не конкурентоспроможної продукції, таким чином знижуючи інвестиційну привабливість [2, с. 81].

3 метою розвитку регіональної економіки важливо залучати значні суми інвестицій i спрямовувати їх у виробничу сферу (промисловість, сільське господарство, будівництво), використовуючи для заміни застарілого i зношеного обладнання, впровадження нових технологій, розширення діючих $\mathrm{i}$ розвитку нових видів виробництв [3].

Капітальні інвестиції — це кошти, що спрямовуються на відтворення основних засобів, розширення, реконструкцію і модернізацію підприємств і споруд, впровадження інновацій у галузях господарства, спорудження житла, шкіл, лікарень та інших об’єктів соціально-культурного призначення тощо. Вони переважно спрямовуються на збільшення основних засобів, інших необоротних матеріальних активів, нематеріальних активів, а також на їх реконструкцію i модернізацію, що призводять до збільшення майбутніх економічних вигод [3].

Розміри капітального інвестування поки що зостаються на невисокому рівні. Як свідчать дослідження (рис. 1), в минулому році рівень валового нагромадження основного капіталу (ВНОК) до ВВП склав лише 12,8\%, що стало історичним мінімумом 3 початку 2000-х років [4]. 


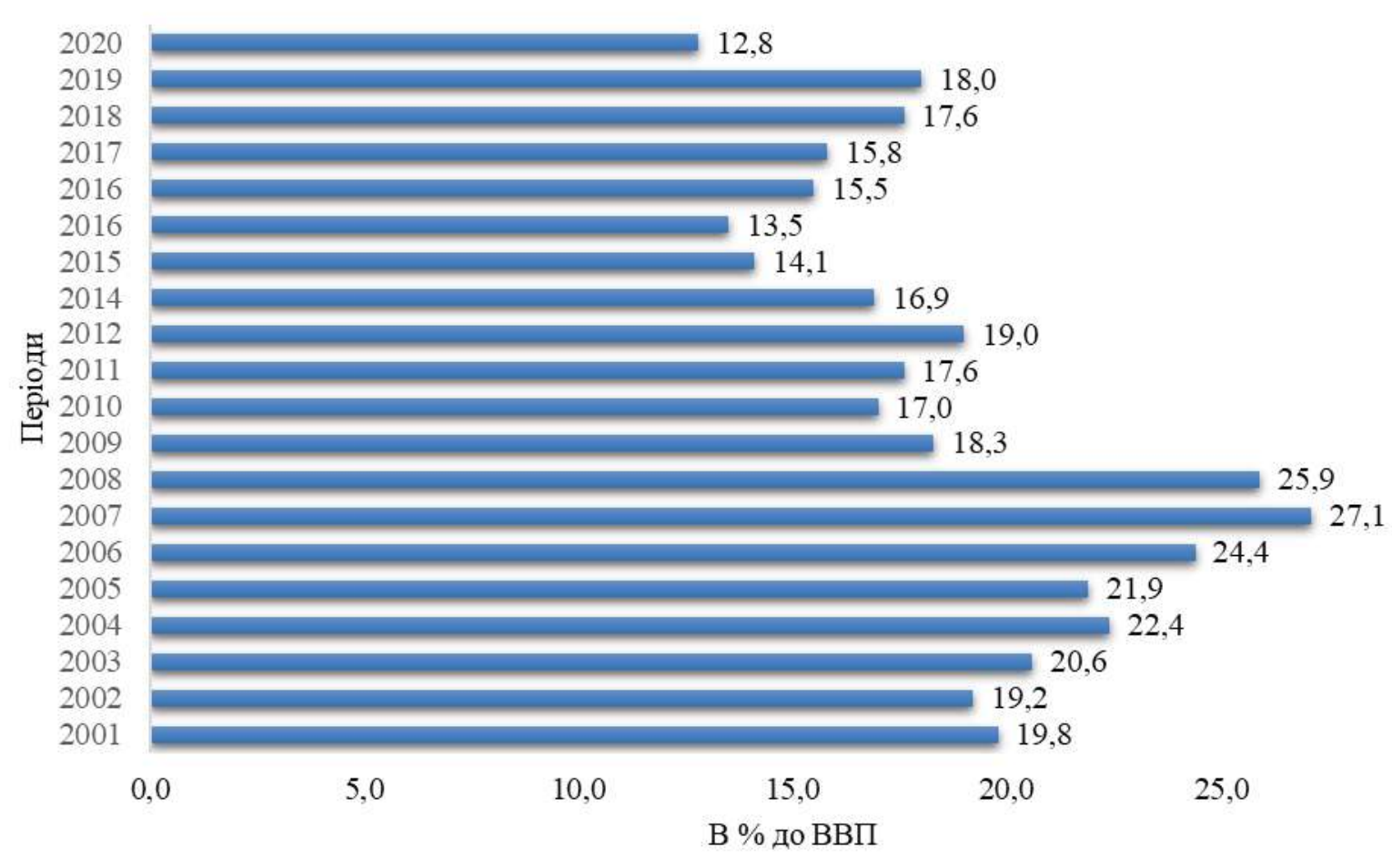

Рис. 1. Валове нагромадження основного капіталу в Украӥні в 2001-2020 рр., $\%$ до ВВП

\section{Джерело: [4]}

Все це відбувається через несприятливий інвестиційний клімат, який спричинений низкою проблем, зокрема:

- недостатній обсяг заощаджень населення, коштів суб'єктів господарювання та держави для здійснення інвестицій із метою реалізації інвестиційних та інноваційних проєктів;

- невизначеність правового інструменту залучення недержавних інвестицій із метою розвитку економіки, зокрема механізму забезпечення розвитку державно-приватного партнерства;

- низькі темпи впровадження високих технологій;

- висока енергоємність внутрішнього валового продукту;

- зношеність основних фондів;

- недосконалість законодавства щодо розвитку інноваційної діяльності;

- невиконання суб'єктами господарювання вимог законодавства щодо взяття на облік об'єктів права інтелектуальної власності й відсутність механізму заохочення введення таких об'єктів у комерційний обіг;

- нерозвинутість інноваційної інфраструктури, недостатня кількість інноваційних підприємств (інноваційних центрів, технопарків, технополісів, інноваційних бізнес-інкубаторів), наукових парків, центрів трансферу технологій і промислових кластерів;

- недосконалість механізму комерціалізації результатів наукових 
досліджень і розробок;

- невизначеність пріоритетів розвитку базових галузей економіки й відсутність сприятливих умов для залучення інвестицій із метою забезпечення розвитку високотехнологічного виробництва;

- незначна кількість вітчизняних виробників високотехнологічної продукції, що беруть участь у міжнародному обміні технологіями, у зв'язку з недосконалістю законодавства щодо трансферу технологій;

- недостатня державна підтримка впровадження інновацій для забезпечення розвитку малого й середнього підприємництва [5];

- відсутність сталої стратегії економічного і політичного розвитку;

- обмеженість державних підприємств, що підлягають приватизації, і в яких зацікавлені потенційні інвестори;

- незабезпеченість усім суб'єктам економічних відносин рівних економічних прав у процесі здійснення фінансово-економічної діяльності;

- складність податкової системи та суттєве податкове навантаження; відсутність надійної інвестиційної історії;

- нестабільна ситуація на Сході країни [6].

У Прогнозі економічного і соціального розвитку України на 2022-2024 роки (далі - Прогноз на 2022-2024 роки), що розроблений Міністерством економіки України за участю зацікавлених центральних органів виконавчої влади зазначається, що більшість економічних агентів взяли інвестиційну паузу: вітчизняні - через втрату фінансових ресурсів внаслідок впливу обмежувальних виробничу діяльність карантинних заходів, іноземні інвестори - через невизначеність щодо термінів і характеру поширення захворюваності та вичікування покращення ситуації [7].

Для визначення заходів, які сприяли б стабілізації розвитку економіки України, захисту i надходженню капітальних інвестицій на макро- i мікрорівнях, важливим є дослідження ситуації з їх обсягом та структурою. За роки незалежності Україна пережила значні коливання в інвестиційному процесі (табл. 1 та рис. 2).

Так, за даними Держкомстату України у 2020 р. порівняно з 2016 р. обсяг інвестицій збільшився на 149,0 млрд грн. Збільшення капітальних інвестицій за цей період характерне для усіх видів економічної діяльності, окрім будівництва (-4,8 млрд грн) та діяльності у сфері адміністративного та допоміжного обслуговування (-1,4 млрд грн) [8]

Найбільший ріст інвестицій характерний для таких галузей: промисловість (+ 62,7 млрд грн), державне управління й оборона (+ 39,9 млрд грн), оптова та роздрібна торгівля; ремонт автотранспортних засобів і мотоциклів $(+11,8$ млрд грн), охорона здоров'я ( + 10,3 млрд грн), транспорт, складське господарство, поштова та кур'єрська діяльність (+ 9,8 млрд грн), інформація та телекомунікації ( + 6,7 млрд грн), професійна, наукова та технічна діяльність ( + 5,2 млрд грн) [8] 
Таблиия 1

Капітальні інвестиції в Україні за видами економічної діяльності за 2016-2020 роки, млрд грн

\begin{tabular}{|c|c|c|c|c|c|c|}
\hline $\begin{array}{c}\text { Види економічної } \\
\text { діяльності }\end{array}$ & 2016 p. & 2017 p. & 2018 p. & 2019 p. & $2020 \mathrm{p}$. & $\begin{array}{c}\text { Відхилення, } \\
\text { (+,-) 2016/ } \\
2020 \text { p. }\end{array}$ \\
\hline Усього & 359,2 & 448,5 & 578,7 & 623,9 & 508,2 & 149,0 \\
\hline $\begin{array}{c}\text { Сільське господарство, лісове } \\
\text { господарство та рибне } \\
\text { господарство }\end{array}$ & 50,5 & 64,2 & 66,1 & 59,1 & 50,7 & 0,2 \\
\hline Промисловість & 117,8 & 143,3 & 199,9 & 254,2 & 180,5 & 62,7 \\
\hline Будівництво & 44,4 & 52,2 & 56,0 & 62,3 & 39,6 & $-4,8$ \\
\hline $\begin{array}{c}\text { Оптова та роздрібна торгівля; } \\
\text { ремонт автотранспортних } \\
\text { засобів і мотоциклів }\end{array}$ & 29,9 & 33,7 & 51,8 & 44,2 & 41,7 & 11,8 \\
\hline $\begin{array}{c}\text { Транспорт, складське } \\
\text { господарство, поштова та } \\
\text { кур'єрська діяльність }\end{array}$ & 25,1 & 37,9 & 50,1 & 43,8 & 34,9 & 9,8 \\
\hline $\begin{array}{c}\text { Тимчасове розміщування й } \\
\text { організація харчування }\end{array}$ & 1,5 & 2,1 & 2,7 & 2,8 & 2,0 & 0,5 \\
\hline $\begin{array}{c}\text { Інформація та } \\
\text { телекомунікації }\end{array}$ & 15,7 & 18,4 & 29,9 & 21,1 & 22,4 & 6,7 \\
\hline $\begin{array}{c}\text { Фінансова та страхова } \\
\text { діяльність }\end{array}$ & 7,7 & 8,1 & 10,7 & 11,2 & 12,0 & 4,3 \\
\hline Операції з нерухомим майном & 19,7 & 22,5 & 27,6 & 28,1 & 20,0 & 0,3 \\
\hline $\begin{array}{c}\text { Професійна, науко-ва та } \\
\text { технічна діяльність }\end{array}$ & 6,6 & 8,0 & 10,8 & 11,9 & 11,8 & 5,2 \\
\hline $\begin{array}{c}\text { Діяльність у сфері } \\
\text { адміністративного та } \\
\text { допоміжного обслуговування }\end{array}$ & 10,0 & 12,7 & 11,8 & 11,7 & 8,6 & $-1,4$ \\
\hline $\begin{array}{c}\text { Державне управління й } \\
\text { оборона }\end{array}$ & 22,4 & 32,8 & 44,6 & 54,3 & 62,3 & 39,9 \\
\hline Освіта & 2,3 & 3,5 & 4,5 & 4,8 & 3,7 & 1,4 \\
\hline Охорона здоров'я & 4,5 & 6,7 & 8,1 & 9,5 & 14,8 & 10,3 \\
\hline $\begin{array}{c}\text { Мистецтво, спорт, розваги та } \\
\text { відпочинок }\end{array}$ & 0,9 & 1,6 & 3,7 & 4,1 & 2,8 & 1,9 \\
\hline Надання інших видів послуг & 0,3 & 0,6 & 0,6 & 0,7 & 0,4 & 0,1 \\
\hline
\end{tabular}

Джерело: складено автором згідно [8]

В галузі сільське господарство, лісове господарство та рибне господарство збільшення інвестицій протягом 2016-2020 років відбулось на 0,2 млрд грн.

Динаміку капітальних інвестиції в Україні за видами економічної 
діяльності за 2016-2020 роки можемо також наглядно спостерігати на рис. 2. Як бачимо капітальні інвестиції за видами економічної діяльності за цей період зросли на $41 \%$.

Далі проаналізуємо капітальні інвестиції за видами активів (табл. 2 та рис. 3).

Як зазначалось раніше, капітальні інвестиції - інвестиції у придбання нових і тих, які були у використанні, або виготовлення власними силами для власного використання матеріальних і нематеріальних активів, витрати на капітальний ремонт та модернізацію.

До інвестицій у матеріальні активи належать інвестиції у житлові та нежитлові будівлі, інженерні споруді, машини, обладнання та інвентар, транспортні засоби, землю, довгострокові біологічні активи тваринництва та рослинництва, інші матеріальні активи. До інвестицій в нематеріальні активи належать інвестицій у придбання або створення власними силами прав користування природними ресурсами та майном, програмного забезпечення та баз даних, прав на комерційні позначення, на об'єкти промислової власності, авторських і суміжних прав, патенти, ліцензії, концесії тощо [9].

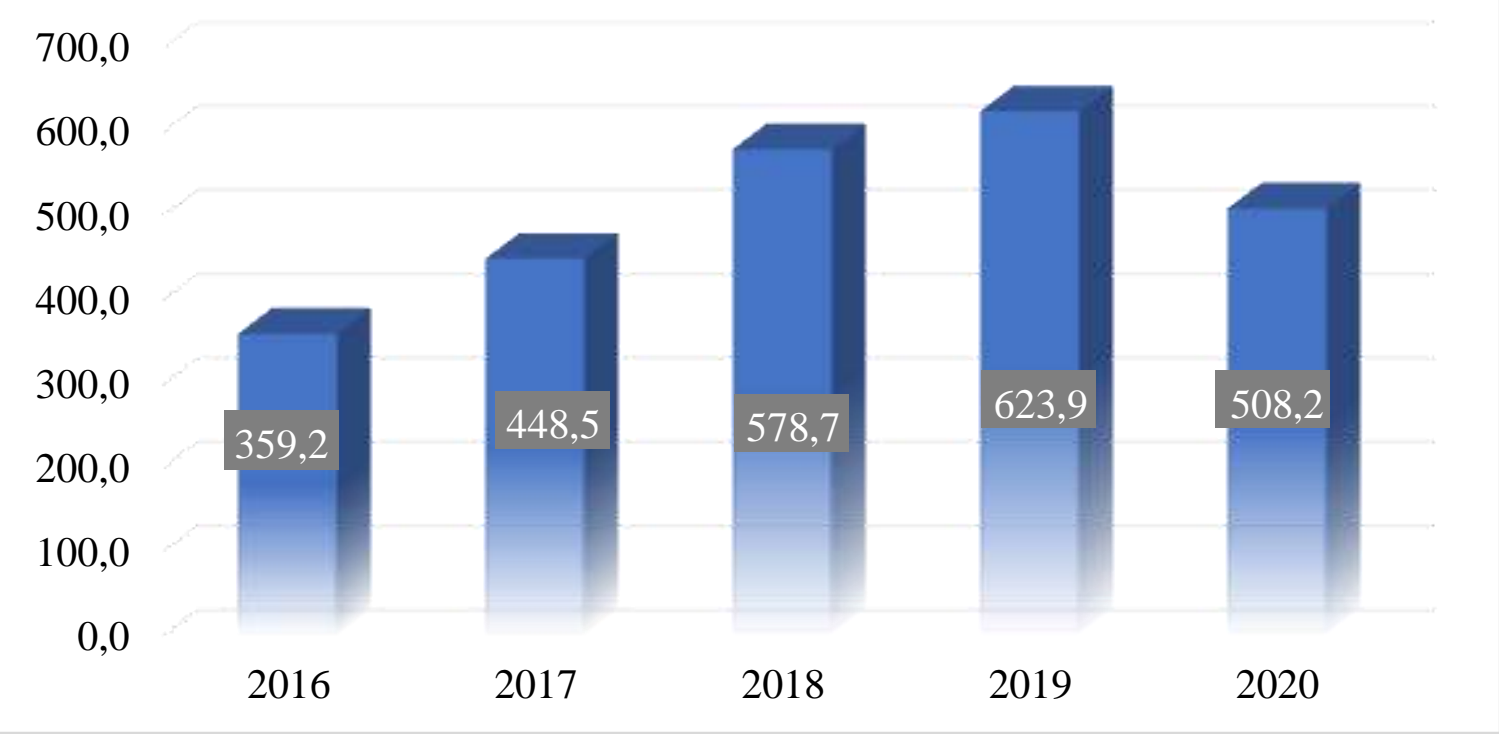

Pис. 2. Динаміка капітальних інвестицій в Украӥні за видами економічної діяльності за 2016-2020 роки, млн грн

Досерело: побудовано автором згідно [8]

3 даних табл. 2 бачимо, що найбільшу частку займають капітальні інвестиції в матеріальні активи, які зросли в 2020 р. порівняно із 2016 р. на 135,9 млрд грн, інвестиції в нематеріальні активи також зросли за період дослідження на 11,6 млрд грн.

Серед матеріальних активів найбільше зросли інвестиції у машини, обладнання та інвентар (+38,5 млрд грн), транспортні засоби $(+13,4$ млрд грн), інженерні споруди (+60,5 млрд грн), нежитлові будівлі (+19,5 млрд грн).

Серед інвестицій в нематеріальні активи, найбільша вартість припадає на програмне забезпечення та бази даних, де інвестиції зросли на 6,1 млрд грн а 
Таблиия 2

\section{Капітальні інвестиції в Україні за видами активів}

за 2016-2020 роки, млрд грн

\begin{tabular}{|c|c|c|c|c|c|c|}
\hline Види активів & 2016 p. & 2017 p. & $2018 p$ & $2019 p$ & $2020 \mathrm{p}$ & \begin{tabular}{|c} 
Відхилення, \\
$(+,-) 2016 /$ \\
2020 p.
\end{tabular} \\
\hline Усього & 359,2 & 448,5 & 578,7 & 623,9 & 508,2 & 149,0 \\
\hline $\begin{array}{c}\text { інвестииії в матеріальні } \\
\text { активи, з них: }\end{array}$ & 347,4 & 432,0 & 542,3 & 600,6 & 483,3 & 135,9 \\
\hline -будівлі житлові & 44,9 & 53,4 & 57,4 & 58,0 & 34,9 & $-10,0$ \\
\hline -будівлі нежитлові & 59,4 & 65,6 & 88,8 & 100,5 & 78,9 & 19,5 \\
\hline інженерні споруди & 67,5 & 78,6 & 111,3 & 149,1 & 128,0 & 60,5 \\
\hline $\begin{array}{c}\text {-машини, обладнання та } \\
\text { інвентар }\end{array}$ & 123,1 & 154,7 & 187,7 & 198,5 & 161,6 & 38,5 \\
\hline -транспортні засоби & 36,7 & 60,1 & 73,9 & 65,9 & 50,1 & 13,4 \\
\hline -земля & 1,9 & 2,0 & 1,7 & 2,2 & 2,3 & 0,4 \\
\hline $\begin{array}{c}\text {-довгострокові біологічні } \\
\text { активи рослинництва та } \\
\text { тваринництва } \\
\end{array}$ & 3,2 & 3,7 & 4,5 & 6,0 & 5,2 & 2,0 \\
\hline -інші матеріальні активи & 10,7 & 13,9 & 17,0 & 20,4 & 22,3 & 11,6 \\
\hline $\begin{array}{c}\text { інвестииїі в нематеріальні } \\
\text { активи, з них: }\end{array}$ & 11,8 & 16,4 & 36,4 & 23,4 & 24,9 & 13,1 \\
\hline $\begin{array}{c}\text {-права на комерційні } \\
\text { позначення, об'єкти - } \\
\text { власності, авторське право та } \\
\text { суміжні з ним права, патенти, } \\
\text { ліцензіі, тощо }\end{array}$ & 4,4 & 6,2 & 24,4 & 8,4 & 8,4 & 4,0 \\
\hline $\begin{array}{c}\text {-програмне забезпечення та } \\
\text { бази даних }\end{array}$ & 6,3 & 8,2 & 9,5 & 10,2 & 12,4 & 6,1 \\
\hline
\end{tabular}

Джерело: складено автором згідно [8]

Наглядно динаміку капітальних інвестицій в Україні за матеріальних та нематеріальних активів за 2016-2020 роки зображено також на рис. 3. Він ще раз підтверджує, що переважають капітальні інвестиції в матеріальні активи. 


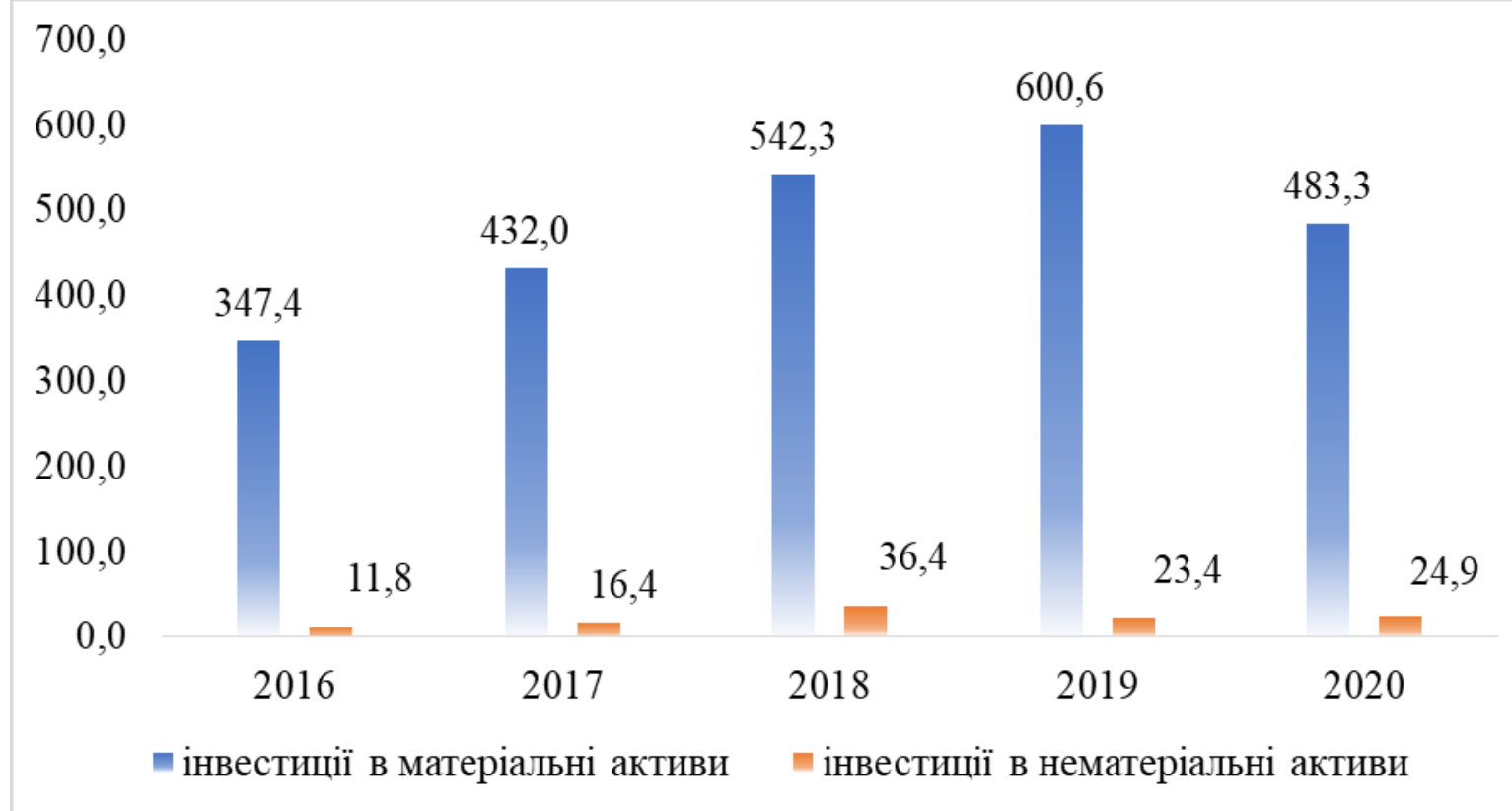

Рис. 3. Динаміка капітальні інвестиції в Україні за матеріальних та нематеріальних активів за 2016-2020 роки, млрд грн

Джерело: побудовано авторами згідно [8]

Важливу роль у збільшенні капітальних інвестицій відіграє їх фінансування, табл. 3.

Як видно із наведених даних, обсяги фінансування капітальних інвестицій в Україні за період 2018-2020 років мають тенденцію до зменшення. Так, в 2020 р. їх скорочення за джерелами фінансування відбулось 106,5 млрд грн.

Таблиия 3

Капітальні інвестиції в Україні за джерелами фінансування за 2018-2020 роки, млн грн.

\begin{tabular}{|c|c|c|c|c|c|c|c|c|}
\hline \multirow[b]{2}{*}{$\begin{array}{l}\text { Види джерел } \\
\text { фінансування }\end{array}$} & \multicolumn{2}{|c|}{2018 p. } & \multicolumn{2}{|c|}{2019 p. } & \multicolumn{2}{|c|}{2020 p. } & \multicolumn{2}{|c|}{$\begin{array}{c}\text { Відхилення, } \\
(+,-) \\
\text { 2020/2018 p. }\end{array}$} \\
\hline & 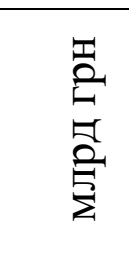 & 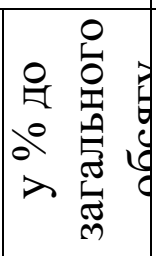 & 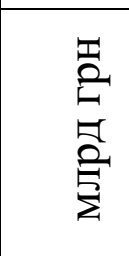 & 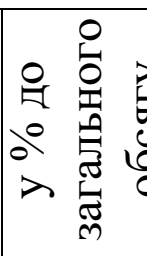 & $\begin{array}{l}\text { 壳 } \\
\text { 章 } \\
\text { 帘 }\end{array}$ & 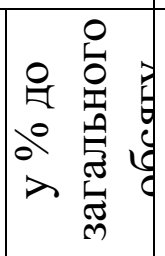 & 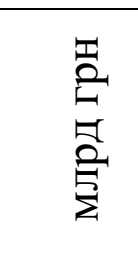 & 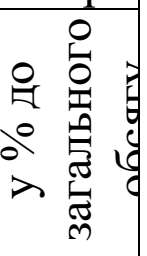 \\
\hline Усього & 526,3 & 100,0 & 584,4 & 100,0 & 419,8 & 100,0 & $\begin{array}{c}- \\
106,5\end{array}$ & \\
\hline у т.ч. за рахунок & & & & & & & & \\
\hline $\begin{array}{c}\text { коштів державного } \\
\text { бюджету }\end{array}$ & 21,0 & 4,0 & 29,5 & 5,0 & 36,5 & 8,7 & 15,5 & 4,7 \\
\hline $\begin{array}{c}\text { коштів місцевих } \\
\text { бюджетів }\end{array}$ & 45,7 & 8,7 & 56,0 & 9,6 & 43,6 & 10,4 & $-2,1$ & 1,7 \\
\hline
\end{tabular}




\begin{tabular}{|c|c|c|c|c|c|c|c|c|}
\hline $\begin{array}{c}\text { власних коштів } \\
\text { підприємств та } \\
\text { організацій }\end{array}$ & 375,3 & 71,3 & 397,8 & 68,1 & 279,3 & 66,5 & $-96,0$ & $-4,8$ \\
\hline $\begin{array}{c}\text { кредитів банків та } \\
\text { інших позик }\end{array}$ & 35,3 & 6,7 & 41,0 & 7,0 & 27,9 & 6,6 & $-7,4$ & $-0,1$ \\
\hline $\begin{array}{c}\text { коштів іноземних } \\
\text { інвесторів }\end{array}$ & 1,5 & 0,4 & 3,5 & 0,6 & 1,7 & 0,6 & 0,2 & 0,2 \\
\hline $\begin{array}{c}\text { коштів населення на } \\
\text { будівництво житла }\end{array}$ & 33,8 & 6,4 & 32,7 & 5,6 & 20,6 & 4,9 & $-13,2$ & $-1,5$ \\
\hline $\begin{array}{c}\text { інших джерел } \\
\text { фінансування }\end{array}$ & 13,6 & 2,6 & 23,9 & 3,3 & 10,2 & 2,4 & $-3,4$ & $-0,2$ \\
\hline
\end{tabular}

Джерело: складено автором згідно [8]

Основним джерелом фінансування капітальних інвестицій у 2020 році були власні кошти підприємств і організацій їх питома вага в загальному обсязі джерел фінансування склала 66,5 \%. Друге місце належить коштам місцевих бюджетів (10,4%). Такий результат в значній мірі спричинений успішними реформами в сфері децентралізації влади. Необхідно відзначити досить незначну участь держави $-8,7$ \%, і особливо іноземних інвесторів $-0,6 \%$.

Якщо розглянути дану проблему в динаміці (табл. 3) то можна відзначити, що основним джерелом фінансування в Україні протягом 2018 - 2020 рр. були власні кошти підприємств та організацій i їх частка в загальному обсязі інвестицій у основний капітал коливалась від 71,3 \% (2018 р.) до 66,5 \% (2020 р.).

Важливе місце в інвестиційній діяльності належить бюджетному інвестуванню, проте в загальному обсязі інвестування кошти державного бюджету мають незначну частку і знаходяться в середньому на рівні 4,0 - 8,7 \%. Разом 3 тим, як зазначалося вище, в результаті початку реформ 3 децентралізації влади, 2018 і по 2020 роки окреслилася позитивна тенденція збільшення капітальних інвестицій за рахунок коштів місцевих бюджетів (відповідно по роках 8,7\%; 9,6\%; 10,4\%).

Однак, слід відзначити продовження негативної тенденції щодо малої частки коштів іноземних інвесторів у загальному обсязі джерел фінансування інвестицій в основний капітал $(0,4-0,6 \%)$.

Наведена аналітика ще раз підтверджує зменшення обсягів капітального інвестування в Україні стосовно останніх років. Скорочення обсягів капітальних інвестицій продемонстрували практично всі види економічної діяльності, iз очікувано найбільш глибоким падінням в галузях сектору послуг (зокрема в сферу мистецтва, спорту, розваг та відпочинку, тимчасове розміщування і організацію харчування, операції з нерухомим майном).

Необхідно зазначити, що для останніх трьох років ще й характерно те, що на

інвестиційний попит в крані, інвестиційну активність суб’єктів 
господарювання, обсяги інвестицій, впливають також наслідки пандеміі COVID-19, причому така ситуація характерна не лише для України а й для інших країн світу.

Зокрема, в країнах Сврозони падіння інвестицій (ВНОК) становило $-10,2$ \% p/p , в т.ч. в Бельгії: -12,2 \% p/p, Словакії: -11,6\% p/p, Польщі: $-5,9$ \% p/p, Чехії: $-4,2$ \% p/p (а частка інвестицій (ВНОК) в загальному обсязі ВВП в цих країнах зменшилась з 24,2 \%, 21,4 \%, 18,5 \% та 26,2 \% в 2019 році до 22,4 \%, 18,5\%, 14,3 \% та 24,4 \% відповідно у I півріччі 2020 року). В Австралії за період з 20 березня по 20 червня 2020 ВНОК скоротився на 6,5 \% p/p. В Китаї в перші два місяці 2020 року інвестиції впали на 24,5\% p/p. Натомість, поступове збільшення капітальних витрат на інфраструктуру, нерухомість, техніку та інші фізичні активи сприяло суттєвому уповільненню падіння інвестицій в економіці Китаю вже за підсумками першого півріччя 2020 року (до -3,1\% p/p). А за попередніми даними Національного бюро статистики КНР, за підсумками січня-вересня 2020 року зростання показника сягнуло 0,8\% p/p [10].

На підтримку бізнесу в умовах пандемії було спрямовано в т.ч. Закон України від 17 березня 2020 року про надання податкових пільг бізнесу на період карантину [11]. Ці пільги здебільшого стосувались відтермінування: строків сплати податків та страхових внесків, строків проведення перевірок та подання податкових декларацій тощо.

Подібні до зазначених вище заходи, спрямовані на підтримку бізнесу в умовах карантину, запроваджувались й іншими країнами Східного партнерства (OECD, 2020). Зокрема в Молдові: перенесення строку сплати податку на прибуток підприємств, зниження ставки ПДВ 320 до 15\% для сектору розміщення та харчування (з 1 травня). У Вірменії: пільгові кредити бізнесу (серед іншого, на придбання обладнання), в Білорусії: надання державними банками підприємствам позик, гарантованих державою тощо [10].

Деякі країни зокрема Німеччина, Китай, Франція, Великобританія, Італія запровадили на період карантину «податкові канікули». Так, в Німеччині знижено ставку ПДВ з 19\% до 16\% на період з липня по грудень 2020 року. В Китаї податкові пільги були поширені на логістичні та кур'єрські компанії, підприємства у сфері транспорту, туризму, готельного та ресторанного бізнесу. У Італії та Великобританії - зниження податків та кредити малому бізнесу. У Франції - відтермінування в сплаті податків [10].

В країнах, де капітальні інвестиції є драйвером економічного зростання (зокрема, Австралія, Австрія, Німеччина, Нова Зеландія, деякі країни Азії), для допомоги бізнесу та стимулювання інвестицій, запроваджувались тимчасові інвестиційні стимули у вигляді прискореної (бонусної) амортизації [10].

Така ситуація спонукає до того, що необхідно здійснювати ряд заходів, що сприятимуть розвитку капітальних інвестицій.

На думку Партин Г. О. та Дідух О. В. найважливішими завданнями щодо розвитку капітального інвестування в Україні $є$ формування сприятливого 
інвестиційного клімату, належного рівня захисту прав інвесторів, проведення політики стимулювання нарощення обсягів капітальних інвестицій до рівня розвинених країн світу та підвищення їхньої ефективності [12]. На їх думку, це забезпечить модернізацію основних засобів підприємств, які сьогодні характеризуються високим рівнем зношення, дасть змогу знизити витрати та підвищити якість продукції українських підприємств, підвищити ї конкурентоздатність на внутрішньому i зовнішньому ринках, а відтак наростити суми доходів і прибутку підприємств та приріст загального обсягу формування ВВП [12].

Гук О., Мохонько Г. та Шендерівська Л. зазначають, що перспективи регулювання процесу розвитку інвестиційної системи в Україні перебувають здебільшого в площині інституціональних перетворень, оскільки саме цей аспект є одним з найбільш значущих і проблемних для національної економіки. Стратегічні орієнтири у вигляді: скорочення відтоку капіталу, забезпечення відтворювальної стійкості; підтримки точок економічного зростання, розвитку територіальних підсистем; забезпечення інноваційності розвитку національної системи інвестування та вітчизняної економіки, вони пропонують реалізувати за допомогою ряду нормативних, організаційно-економічних важелів, а саме:

- підтримки реінвестування капіталу за допомогою пільгового інвестиційно-орієнтованого оподаткування (в секторальному та проєктному вимірах);

- впровадження стимулів для інвестування в реальний сектор економіки для установ банківсько-фінансової сфери;

- скасування непродуктивних пільг і прямих дотацій;

- запровадження інвестиційно-орієнтованих перспективних пільг 3 оподаткування прибутку при реалізації стратегічно значущих проєктів, застосування попроєктного підходу в діючому податковому законодавстві;

- капіталізації інформаційно-інтелектуальних внесків при супроводженні інвестиційних проєктів на регіональному рівні, формування фондів інвестиційної підтримки;

- інвестиційно-орієнтованого використання фінансових ресурсів ДФРР (Державного фонду регіонального розвитку) та реверсних дотацій територіальних громад (на проєкти співробітництва);

- пільгового режиму оподаткування прибутку, реінвестованого в наукову діяльність, інноваційний розвиток, підготовку висококваліфікованих кадрів [13].

Очередько О.О. вважає, що в умовах існування економічних i політичних ризиків, внутрішніх, i зовнішніх, запорукою поліпшення інвестиційної діяльності підприємств в Україні $є$ послідовне здійснення кроків, які задекларував уряд:

- проведення реформи судової системи і правоохоронних органів,

- здійснення системної протидії корупції, 
- забезпечення прозорості державних закупівель,

- суттєва дерегуляція економіки відповідно до європейських стандартів ведення бізнесу [14, с. 30].

Враховуючи зазначені проблеми, з якими стикається Україна на шляху розвитку ринкової економіки, для ефективного залучення інвестицій необхідно створити сприятливе середовище для ведення бізнесу; зменшити кількість документів та актів, які ускладнюють процес діяльності підприємства та перешкоджають розвитку малого і середнього бізнесу; скоротити кількість органів державного контролю, забезпечити надання допомоги від держави для підтримки бізнесу; для підтримки іноземних інвесторів та кредиторів потрібно розробити ефективне страхування та забезпечити захист права приватної власності; забезпечити захист прав інтелектуальної власності; змінити законодавство у сфері іноземного інвестування, максимально наблизити його до європейського рівня для того, щоб зменшити побоювання інвесторів та створити для них комфортні умови [6].

Перераховані пропозиції мають становити основу системи державних, регіональних i галузевих інноваційно-інвестиційних програм та отримати першочергову підтримку. Їх вирішення несе позитивний вплив на інноваційноінвестиційну привабливість країни в цілому та їх регіонів зокрема. Інноваційно-інвестиційний процес має бути регульованим і регіон повинен формувати ефективну інвестиційну політику, направлену на покращення іiі привабливості [6].

Щодо можливих шляхів поліпшення інвестиційного клімату в Україні та активнішого залучення прямих іноземних інвестицій в пріоритетні сектори національної економіки, Боярко I.М. та Гриценко Л.Л. зазначають, що на їх думку доцільною видається реалізація таких заходів:

- розбудова національної фінансової системи в напрямку створення механізмів довгострокового інвестиційного кредитування, конкурсного розподілу державних інвестиційних ресурсів, ефективної концентрації заощаджень населення для фінансування цілей економічного розвитку;

- прискорення реформування амортизаційної системи шляхом іiі лібералізації та посиленняінвестиційної спрямованості;

- впровадження механізмів участі індивідуальних інвесторів в операціях на фінансовому ринку;

- створення надійної правової основи для стимулювання і залучення приватних інвестицій в інститути розвитку;

- розробка плану дій щодо формування сприятливого інвестиційного клімату у межах проголошених пріоритетів соціально-економічного розвитку, розробка регіональних планів підвищення інвестиційної привабливості областей з урахуванням особливостей їхнього ресурсногопотенціалу;

- розвиток державно-приватного партнерства в підтримці інвестиційної та інноваційної діяльності; 


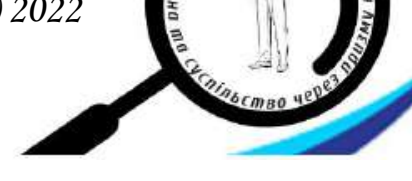

- забезпечення постійної взаємодії органів виконавчої влади i підприємців, покращення інформаційного супроводження реалізації інвестиційних проектів;

- розвиток програм довгострокового кредитування індивідуальних інвестицій у тому числі в підвищення енергетичної економічності житла, освіту, житлове будівництво тощо [15, с. 123].

Усе вищевикладене, свідчить про те що рекомендації, що пропонуються науковцями щодо пожвавлення інвестиційної активності, стосуються перш за все законодавчої бази, регулювання інвестиційної діяльності, організації ведення бізнесу, розвитку державно-приватного партнерства, співпраці 3 органи виконавчої влади тощо.

Висновки. Розвиток діяльності господарюючих суб'єктів та економіки країни в цілому, неможливий без запровадження ефективної інвестиційної діяльності, достатнього рівня інвестицій, спрямованості їх в пріоритетні галузі національного господарства та ефективного використання. Зміцнення виробничої діяльності усіх господарюючих суб’єктів, поліпшення суспільного відтворення, неможливе без інтенсифікації відтворення та покращання використання діючих основних засобів за рахунок капітальних інвестицій. Інвестиції є важливим фактором прогресивного розвитку кожної економічної системи. Вони виконують роль каталізатора виробництва i $\epsilon$ потужним стимулом до переоснащення, модернізації технічної бази підприємств, що підвищує їх конкурентоспроможність на ринку.

За результатами проведеного дослідження динаміки та структури капітальних інвестицій визначено, що розміри капітального інвестування поки що залишаються на невисокому рівні. В 2020 році рівень валового нагромадження основного капіталу до ВВП склав лише 12,8\%, що стало історичним мінімумом 3 початку 2000-х років. Така ситуація спричинена несприятливим інвестиційним кліматом, який асоціюється 3 рядом проблем, зокрема: нестабільність і недосконалість нормативно-правової бази, політична нестабільність, недостатній рівень розвитку валютного регулювання, нерозвинутість фондового ринку, значний податковий тиск, низький рівень забезпечення привабливості об’єктів інвестування, малоефективна інвестиційна діяльність банків, низький рівень трансформації заощаджень населення в інвестування, недостатня кількість вільних економічних та офшорних зон, корупційні процеси тощо.

Для того аби збільшити інвестиції в підприємницьку діяльність, необхідно: вдосконалити нормативно-правову базу, яка б чітко визначала права інвесторів та давала їм можливість вільно вкладати вільні кошти в підприємства України; створити освітні центри, які б навчали та інформували громадян України щодо інвестиційної діяльності, а також надавали приклади щодо залучення іноземних інвесторів; запозичити міжнародний досвіт щодо інвестиційної діяльності підприємств [16]. 
Заходи щодо активізації інвестиційної діяльності суб'єктів господарювання мають здійснюватись на всіх рівнях та етапах господарювання. Необхідно забезпечити сприятливий інвестиційний клімат не лише для іноземних інвесторів, але й для українських. Пожвавлення інвестиційної активності здійсненне шляхом комплексних, рішучих та послідовних дій, сприятимуть створенню конкурентного осередку та стимулів ефективного розвитку суб'єктів господарювання та економіки країни в цілому.

\section{Jimepamypa:}

1. Мулик Т.О. Оцінка стану та перспектив розвитку інвестиційної діяльності підприємств України. Економіка, фінанси, менеджмент: актуальні питання науки $i$ практики. 2019. № 7. С. 46-56.

2. Gutsalenko L., Wasilewski M., Mulyk T., Marchuk U., Mulyk Ya. Accounting control of capital investment management: realities of Ukraine and Poland. Economic annals - XXI. 2018. № 170(3-4). P. 79-84.

3. Звіт "Аналіз стану інвестиційної діяльності Вінницької, Запорізької, Івано-Франківської та Полтавської областей та практичні рекомендації щодо поліпшення інвестиційного середовища". URL: http://pleddg.org.ua/wp-content/uploads/2016/10/Analysisof-Investment-Preacticies_Report_26052016_Last.pdf

4. Власюк В. Що не так 3 капітальними інвестиціями в Україні. URL: https://www.epravda.com.ua/columns/2021/05/6/673627/

5. Розвиток інвестиційної та інноваційної діяльності в Україні. URL: https://zet.in.ua/ statistika-2/rozvitok-investicijno\%D1\%97-ta-innovacijno\%D1\%97-diyalnosti-v-ukra\%D1\%97ni/

6. Осіпова Л. В., Саєнко Я. А. Активізація інвестиційної діяльності України в умовах нестабільної економіки: регіональний аспект. Вісник Хмельницького наиіонального університету. 2020. № 2. С.114-120.

7. Прогноз економічного і соціального розвитку України на 2022-2024 роки. URL: https://www.me.gov.ua/Documents/Detail?lang=uk-UA\&id=77059300-efc0-4c61-8a67-

3974e0cd27a5\&title=PrognozEkonomichnogoISotsialnogoRozvitkuUkraini

8. Державна служба статистики Украіни: офіційний сайт. URL: http://www.ukrstat.gov.ua

9. Капітальні інвестиції. Методологічні пояснення. http://www.od.ukrstat.gov.ua/stat_ info/invest/invest $13 . \mathrm{htm}$

10.Яценко Г. Інвестиційний попит в Україні: динаміка та шляхи стимулювання в умовах пандемії COVID-19. URL: https://lb.ua/blog/hanna_yatsenko/470235_investitsiyniy popit_ukraini.html

11. Про внесення змін до Податкового кодексу України та інших законів України щодо соціальної підтримки платників податків на період здійснення обмежувальних протиепідемічних заходів, запроваджених з метою запобігання поширенню на території України гострої распіраторної хвороби COVID-19, спричиненої коронавірусом SARS-Co V-2: Закон України від 07.12.2020 p. № 1072-IX.

12. Партин Г. О., Дідух, О. В. Капітальні інвестиції: сутність, сучасні тенденції та вплив на зростання обсягів ВВП. Ефективна економіка. 2021. № 3. URL: http://www.economy.nayka.com.ua/?op=1\&z=8756 DOI: 10.32702/2307-2105-2021.3.86

13. Гук О., Мохонько Г., Шендерівська Л. (2021). Тенденції інвестування в Україні. Економіка та суспільство, 2021. № 29. URL: https://economyandsociety.in.ua/ index.php/journal/article/view/577/553 DOI: 10.32782/2524-0072/2021-29-35

14. Очередько О.О. Перспективи розвитку інвестиційної діяльності підприємств 
У країни. Менеджер. 2016. № 4 (73). С. 24 - 31.

15. Боярко І.М. Гриценко Л.Л. Інвестиційний аналіз: навчальний посібник. К.: Центр учбовоїлітератури, 2012. 400 с.

16. Суханова А.В., Котик Б.Ю. Сучасний стан та перспективи розвитку інвестиційної діяльності підприємств в Україні. Економіка та суспільство. 2018. №19. C.641-645 DOI: https://doi.org/10.32782/2524-0072/2018-19-100

\section{References:}

1. Mulyk, T.O. (2019) Otsinka stanu ta perspektyv rozvytku investytsiinoi diialnosti pidpryiemstv Ukrainy [Assessment of the state and prospects of development of investment activity of Ukrainian enterprises]. Ekonomika, finansy, menedzhment: aktualni pytannia nauky i praktyky.- Economics, finance, management: current issues of science and practice, 7, 46-56 [in Ukrainian].

2. Gutsalenko L., Wasilewski M., Mulyk T., Marchuk U. \& Mulyk Ya. (2018) Oblikovokontrolne zabezpechennia upravlinnia kapitalnymy investytsiiamy: realii sohodennia Ukrainy ta Polshchi [Accounting control of capital investment management: realities of Ukraine and Poland]. Ekonomichnyi chasopys- XXI - Economic annals - XXI, 170(3-4). 79-84 [in Ukrainian].

3. Zvit "Analiz stanu investytsiinoi diialnosti Vinnytskoi, Zaporizkoi, Ivano-Frankivskoi ta Poltavskoi oblastei ta praktychni rekomendatsii shchodo polipshennia investytsiinoho seredovyshcha" [Report "Analysis of the state of investment activity of Vinnytsia, Zaporizhia, Ivano-Frankivsk and Poltava regions and practical recommendations for improving the investment environment"]. Retrieved from: http://pleddg.org.ua/wp-content/uploads/2016/10/Analysis-ofInvestment-Preacticies_Report_26052016_Last.pdf [in Ukrainian].

4. Vlasiuk, V. (2021) Shcho ne tak z kapitalnymy investytsiiamy v Ukraini [What is wrong with capital investment in Ukraine]. Retrieved from: https://www.epravda.com.ua/columns/ 2021/05/6/673627/ [in Ukrainian].

5. Rozvytok investytsiinoi ta innovatsiinoi diialnosti v Ukraini [Development of investment and innovation activities in Ukraine] Retrieved from: https://zet.in.ua/statistika-2/rozvitokinvesticijno\%D1\%97-ta-innovacijno\%D1\%97-diyalnosti-v-ukra\%D1\%97ni/ [in Ukrainian].

6. Osipova, L. V. \& Saienko, Ya. A. (2020) Aktyvizatsiia investytsiinoi diialnosti Ukrainy v umovakh nestabilnoi ekonomiky: rehionalnyi aspekt [Activation of investment activity of Ukraine in the conditions of unstable economy: regional aspect]. Visnyk. Khmelnytskoho natsionalnoho universytetu - Bulletin of Khmelnytsky National University, 2, 114-120 [in Ukrainian].

7. Prohnoz ekonomichnoho i sotsialnoho rozvytku Ukrainy na 2022-2024 roky [Forecast of economic and social development of Ukraine for 2022-2024]. Retrieved from: https://www.me.gov.ua/Documents/Detail?lang=uk-UA\&id=77059300-efc0-4c61-8a67-

3974e0cd27a5\&title=PrognozEkonomichnogoISotsialnogoRozvitkuUkraini [in Ukrainian].

8. Derzhavna sluzhba statystyky Ukrainy: ofitsiinyi sait [Government service of statistics of Ukraine: official web-site] Retrieved from:http://www.ukrstat.gov.ua. [in Ukrainian].

9. Kapitalni investytsii. Metodolohichni poiasnennia. [Capital investment. Methodological explanations ]. Retrieved from: http://www.od.ukrstat.gov.ua/stat_info/invest/invest13.htm [in Ukrainian].

10. Iatsenko, H. (2020) Investytsiinyi popyt v Ukraini: dynamika ta shliakhy stymuliuvannia $\mathrm{v}$ umovakh pandemii COVID-19 [Investment demand in Ukraine: dynamics and ways of stimulation in the conditions of the COVID-19 pandemic]. Retrieved from: https://lb.ua/blog/hanna_yatsenko/470235_investitsiyniy_popit_ukraini.html [in Ukrainian].

11. Pro vnesennia zmin do Podatkovoho kodeksu Ukrainy ta inshykh zakoniv Ukrainy shchodo sotsialnoi pidtrymky platnykiv podatkiv na period zdiisnennia obmezhuvalnykh protyepidemichnykh zakhodiv, zaprovadzhenykh $\mathrm{z}$ metoiu zapobihannia poshyrenniu na terytorii Ukrainy hostroi raspiratornoi khvoroby COVID-19, sprychynenoi koronavirusom SARS-Co V-2: 
Zakon Ukrainy [On amendments to the Tax Code of Ukraine and other laws of Ukraine on social support of taxpayers for the period of restrictive anti-epidemic measures introduced to prevent the spread of acute respiratory disease COVID-19 caused by coronavirus SARS-Co V-2: [The Law of Ukraine ] (n.d.). zakon.rada.gov.ua. Retrieved from https://zakon.rada.gov.ua/laws/show/1072-20\#Text [in Ukrainian].

12.Partyn, H. O. \& Didukh, O. V. (2021) Kapitalni investytsii: sutnist, suchasni tendentsii ta vplyv na zrostannia obsiahiv VVP [Capital investment: the essence, current trends and impact on GDP growth]. Efektyvna ekonomika - Efficient economy, 3. Retrieved from: http://www.economy.nayka.com.ua/?op= 1\&z=8756 DOI: 10.32702/2307-2105-2021.3.86 [in Ukrainian].

13. Huk, O., Mokhonko, H. \& Shenderivska, L. (2021). Tendentsii investuvannia v Ukraini [Investment trends in Ukraine]. Ekonomika ta suspilstvo - Economy and society, 29. Retrieved from: https://economyandsociety.in.ua/ index.php/journal/article/view/577/553 DOI: 10.32782/2524-0072/2021-29-35 [in Ukrainian].

14. Ocheredko, O.O. (2016). Perspektyvy rozvytku investytsiinoi diialnosti pidpryiemstv Ukrainy [Prospects for development of investment activity of Ukrainian enterprises]. MenedzherManager, 4 (73), 24 - 31 [in Ukrainian].

15. Boiarko, I.M. \& Hrytsenko, L.L. (2012). Investytsiinyi analiz: navchalnyi posibnyk. [Investment analysis]. Kyiv. Tsentr uchbovoi literatury [in Ukrainian].

16. Sukhanova, A.V. \& Kotyk, B.Iu. (2018) Suchasnyi stan ta perspektyvy rozvytku investytsiinoi diialnosti pidpryiemstv v Ukraini [Current state and prospects of investment activity of enterprises in Ukraine]. Ekonomika ta suspilstvo - Economy and society, 19. 641-645 DOI: https://doi.org/10.32782/2524-0072/2018-19-100 [in Ukrainian]. 